The National Bureau of Standards ${ }^{1}$ was established by an act of Congress March 3, 1901. The Bureau's overall goal is to strengthen and advance the Nation's science and technology and facilitate their effective application for public benefit. To this end, the Bureau conducts research and provides: (1) a basis for the Nation's physical measurement system, (2) scientific and technological services for industry and government, (3) a technical basis for equity in trade, and (4) technical services to promote public safety. The Bureau consists of the Institute for Basic Standards, the Institute for Materials Research, the Institute for Applied Technology, the Center for Computer Sciences and Technology, and the Office for Information Programs.

THE INSTITUTE FOR BASIC STANDARDS provides the central basis within the United States of a complete and consistent system of physical measurement; coordinates that system with measurement systems of other nations; and furnishes essential services leading to accurate and uniform physical measurements throughout the Nation's scientific community, industry, and commerce. The Institute consists of a Center for Radiation Research, an Office of Measurement Services and the following divisions:

Applied Mathematics-Electricity-Heat-Mechanics-Optical Physics-Linac Radiation ${ }^{2}$ - Nuclear Radiation'-2 Applied Radiation ${ }^{2}$ - Quantum Electronics ${ }^{3}$ Electromagnetics ${ }^{3}$ - Time and Frequency ${ }^{3}$ - Laboratory Astrophysics ${ }^{3}$ - Cryogenics ${ }^{3}$.

THE INSTITUTE FOR MATERIALS RESEARCH conducts materials research leading to improved methods of measurement, standards, and data on the properties of well-characterized materials needed by industry, commerce, educational institutions, and Government; provides advisory and research services to other Government agencies; and develops, produces, and distributes standard reference materials. The Institute consists of the Office of Standard Reference Materials and the following divisions:

Analytical Chemistry-Polymers-Metallurgy-Inorganic Materials-Reactor Radiation-Physical Chemistry.

THE INSTITUTE FOR APPLIED TECHNOLOGY provides technical services to promote the use of available technology and to facilitate technological innovation in industry and Government; cooperates with public and private organizations leading to the development of technological standards (including mandatory safety standards), codes and methods of test; and provides technical advice and services to Government agencies upon request. The Institute also monitors NBS engineering standards activities and provides liaison between NBS and national and international engineering standards bodies. The Institute consists of the following technical divisions and offices:

Engineering Standards Services-Weights and Measures-Flammable FabricsInvention and Innovation-Vehicle Systems Research-Product Evaluation Technology-Building Research-Electronic Technology-Technical AnalysisMeasurement Engineering.

THE CENTER FOR COMPUTER SCIENCES AND TECHNOLOGY conducts research and provides technical services designed to aid Government agencies in improving cost effectiveness in the conduct of their programs through the selection, acquisition, and effective utilization of automatic data processing equipment; and serves as the principal focus within the executive branch for the development of Federal standards for automatic data processing equipment, techniques, and computer languages. The Center consists of the following offices and divisions:

Information Processing Standards-Computer Information-Computer Services - Systems Development-Information Processing Technology.

THE OFFICE FOR INFORMATION PROGRAMS promotes optimum dissemination and accessibility of scientific information generated within NBS and other agencies of the Federal Government; promotes the development of the National Standard Reference Data System and a system of information analysis centers dealing with the broader aspects of the National Measurement System; provides appropriate services to ensure that the NBS staff has optimum accessibility to the scientific information of the world, and directs the public information activities of the Bureau. The Office consists of the following organizational units:

Office of Standard Reference Data-Office of Technical Information and Publications-Library-Office of Public Information-Office of International Relations.

\footnotetext{
1 Headquarters and Laboratories at Gaithersburg, Maryland, unless otherwise noted; mailing address Washington, D.C. 20234

2 Part of the Center for Radiation Research.

Located at Boulder, Colorado 80302.
} 
UNITED STATES DEPARTMENT OF COMMERCE • Maurice H. Stans, Secretary NATIONAL BUREAU OF STANDARDS • Lewis M. Branscomb, Director

\title{
Universal Testing Machine of 12-Million-lbf Capacity At the National Bureau of Standards
}

\author{
Arthur F. Kirstein \\ Mechanics Division \\ Institute for Basic Standards \\ National Bureau of Standards
}

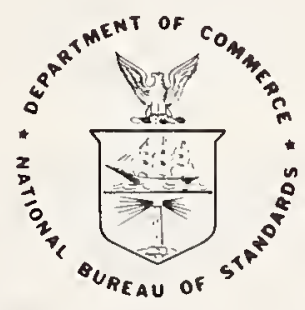

National Bureau of Standards Special Publication 355

Nat. Bur. Stand. (U.S.), Spec. Publ. 35518 pages (Sept. 1971)

CODEN: XNBSA

Issued September 1971 
As a result of a number of structural failures, exemplified by the disastrous collapse of a lattice column during erection of the first Quebec bridge in 1907, the Federal Government became deeply involved in structuralmaterial testing. In 1910 this work was consolidated at the National Bureau of Standards and expanded through the acquisition of a 10,000,000 lbf compression testing machine originally contracted for by the Geological Survey.

This large testing machine, and other facilities of the Engineering Mechanics Section of NBS, were used for extensive research into the mechanical behavior of such structural components as columns, struts, masonry walls, ship structures, and bridge members. When the NBS relocation to the Gaithersburg, Maryland, site was being planned, it was evident that the $10,000,000$ lbf capacity machine was inadequate for current and projected needs. A modern machine, incorporating the technological advances of recent years, was needed to enable NBS to continue its leadership in research on large structural components and in calibration of large force measuring devices. These plans resulted in the development and construction of a unique $12,000,000$ lbf capacity universal testing machine.

This machine represents a significant addition to the Nation's facilities for research and testing in the field of large structures. The National Bureau of Standards we1comes the opportunity to use this unique facility in cooperation with academic, industrial and government organizations in solving a wide variety of problems of National concern.

Lewis M. Branscomb, Director 
TABLE OF CONTENTS

1. INTRODUCTION . . . . . . . . . 1

2. PRINCIPAL DIMENSIONS . . . . . . . . 2

3. FOUNDATION AND TIE-DOWN FLOOR SYSTEM • . 2

4. LOADING STRUCTURE • . . . . . . . . 3

5. FORCE MEASURING SYSTEM • • . • • . . 3

6. CONTROL CONSOLE . . . . . . . . . . . 4

7. ACCESSORIES . . . . . . . . . . 5

8. RESEARCH AND FORCE CALIBRATION . . . . . 6

9. SUMMARY . . . . . . . . . . . . . 6

10. REFERENCES . . . . . . . . . . . . 7

FIGURES . . . . . . . . . . . . 8-14

Library of Congress Catalog Card Number: 73-179678 
In view of present accepted practice in this technological area, U. S. customary units of measurement have been used throughout this paper. It should be noted that the U. S. is a signatory to the General Conference on Weights and Measures which gave official status to the metric SI system of units in 1960. Readers interested in making use of the coherent system of SI units will find conversion factors in ASTM Standard Metric Practice Guide, ASTM Designation E 380-70 (available from American Society for Testing and Materials, 1916 Race Street, Philadelphia, Pennsylvania 19103). Conversion factors for units used in this paper are:

Length

Force

Stress

Moment

Mass

${ }^{*}$ Exact values
1 in $=0.0254^{*}$ meter

$1 \mathrm{ft}=0.3048^{*}$ meter

$1 \mathrm{lbf}=4.448$ newton

$1 \mathrm{lbf} / \mathrm{in}^{2}=6895$ newton $/$ meter $^{2}$

1 lbf-ft $=1.356$ newton meter

1 ton $=907.2 \mathrm{kilograms}$

$1 \mathrm{Ib}=0.4536 \mathrm{kilograms}$ 
Universal Testing Machine of 12-Million-1bf Capacity at the National Bureau of Standards

\author{
Arthur F. Kirstein
}

A 12-million pounds-force capacity universal testing machine, which is believed to be the largest of its kind in the world, has been put into operation in the Engineering Mechanics Laboratory of the National Bureau of Standards in Gaithersburg, Maryland. This hydraulically operated machine, which has an overall height of over 100 feet, was designed to test full scale structural components and to apply the forces needed to calibrate large capacity force measuring devices. The testing machine is capable of applying axial forces of $12,000,000$ lbf in compression, 6,000,000 $\mathrm{lbf}$ in tension, and a transverse force of 4,000,000 lbf to a flexural specimen.

Key words: Force calibration; large test facilities; structural testing; universal testing machine.

\title{
1. INTRODUCTION
}

For many years the National Bureau of Standards has been aware of the increasing requirements for a large force generating facility which would be suitable for tests of large full scale structural components and for calibration of large force measuring devices. To satisfy these requirements, plans were made for the design and construction of a $12,000,0001 \mathrm{bf}$ capacity universal testing machine--plans which were consummated with the construction of a new large testing facility in the Engineering Mechanics Laboratory in Gaithersburg, Maryland (fig. 1).

This hydraulically operated machine is a vertical, four-screw type with the main fixed platen flush with the floor (fig. 2). It projects approximately 78 feet above the floor level, and extends about 23 feet into a pit. It is capable of applying 12,000,000 lbf in compression, $6,000,000 \mathrm{lbf}$ in tension, and 4,000,000 lbf to a flexural specimen.

This new universal testing machine has replaced a 10,000,000 1bf capacity compression testing machine, which has been in service since the early nineteen-hundreds. A comparison of the features of the new machine, described in this paper, to those of the 10,000,000 1bf machine, as given in references 1 and 2, will show the many advances that have been made through the years and are incorporated in this new machine. 
The 12,000,000 lbf capacity universal testing machine, shown in figure 3, projects approximately 78 feet above the floor and extends about 23 feet below into a pit. The overall height of the machine is then approximately 101 feet, and its gross weight is about 2,000,000 pounds. The base of the machine is attached to its reinforced concrete foundation with a prestress force of 4,000,000 lbf. A test floor 90 feet long is an integral part of this foundation.

The test openings and the sizes of the test fixtures govern the sizes of specimens that can be tested in this machine. The vertical opening between the bedplate, which rests on the main platen (fig. 2), and the compression leveling plate assembly, which is on the sensitive crosshead, is infinitely adjustable along the screw columns to provide vertical openings up to 58 feet for compression tests. For tension tests the vertical opening from the top of the sensitive crosshead to the bottom of the tension crosshead is infinitely adjustable from zero to 53 feet. These dimensions allow for the full 5 foot power stroke of the main hydraulic cylinder. For convenience, the tension head can be 1ocated at the notched positions along the two main columns as shown in figure 3. These notches are located $32,42,52,62$, and 72 feet above the main platen of the machine. Both of the test openings given above can be increased by two feet if the compression leveling plate assembly and the bedplate are removed from the machine. The clear horizontal working space between the screw columns is 8 feet 4 inches, and the working surface of the main platen is 8 feet 4 inches by 15 feet. The bedplate is 7 feet in diameter and 1 foot thick. The working surface of the foundation, which extends beyond the main platen, contains a tiedown floor system that can be used to support transverse or flexural specimens up to 90 feet in length.

\section{FOUNDATION AND TIE-DOWN FLOOR SYSTEM}

The reinforced concrete foundation for this machine includes a tiedown floor system which provides the capability to perform transverse or flexural tests on specimens up to 90 feet in length. A plan view of the foundation is shown in figure 4. The pit through the central portion contains the hydraulic and electric equipment to operate the machine as well as the lower 23 feet of the machine. The overall dimensions of the tie-down floor are 90 feet in length and 16 feet 8 inches in width. Other pertinent dimensions of the 126 tie-down bolt locations are shown in figure 4. 
The working strength values for the tie-down floor system are:

Longitudinal bending moment

(over central 40 feet)

Tranverse bending moment

(over central 40 feet)

Uniform bearing

Tensile force on anchor bolts
$12,500,0001 \mathrm{bf}-\mathrm{ft}$

$20,000,000 \mathrm{lbf}-\mathrm{ft}$

$467,0001 \mathrm{bf-ft} / \mathrm{ft}$ of width

$750,0001 \mathrm{bf-ft} / \mathrm{ft}$ of width

$9401 \mathrm{bf} / \mathrm{in}^{2}$

$150,0001 \mathrm{bf} / \mathrm{bolt}$

\section{LOADING STRUCTURE}

The loading structure consists of a fixed frame and a movable frame. The fixed frame is built around the main platen and includes the main platen, main columns, top tie plate, and tension crosshead (fig. 3). The movable frame is supported by the fixed frame, and includes the main hydraulic cylinder, screw columns, and sensitive crosshead. Compression tests are performed between the sensitive crosshead and the bedplate, and tension tests are performed between the sensitive and tension crossheads. Flexural tests may be performed between the sensitive crosshead and either the main platen or the tie-down floor system. In all cases the test load is applied by pressurizing the main hydraulic cylinder which pulls the screw columns through the main platen thus drawing the sensitive crosshead downward and providing the force required for compression, tension, or flexural testing.

An important feature of the loading structure is the backlash elimination system, which locks the sensitive crosshead to the screw columns. This feature prevents recoil damage to the threads of both the screw columns and drive nuts of the crosshead. It also provides for greater stability of the movable frame.

\section{FORCE MEASURING SYSTEM}

Two hydraulic capsules are installed in the sensitive crosshead. One of these annular cells provides the force measuring function for compression, tension, and flexural testing. The other cell provides the preloading that is required for proper operation of the force measuring cel1. Pressure transducers, located within a constant temperature oven on the sensitive crosshead, sense the pressure within the force measuring cell and transform it into an electrical signal. This signal is transmitted to the control console where the applied load, in poundsforce, is displayed by analog and/or digital indicating systems. The full scale ranges of these indicating systems are: 
Analog ranges

$1 \mathrm{bf}$

$12,000,000$

$6,000,000$

$3,000,000$

$1,200,000$

600,000
Digital ranges

$1 \mathrm{bf}$

$12,000,000$

$1,200,000$

120,000

Al1 ranges have been calibrated, and generally do not exhibit errors greater than 0.5 percent of the applied load.

There are two other features incorporated in the force measuring system which are worthy of note. One device is incorporated with the analog indicator to transmit force measurement output signals directly to a data acquisition system. This records the force along with the strain and displacement measurements for future reference and study, and also provides the machine operator with a visual means to monitor and control the progress of the test. The other device provides for the use of an auxiliary (external) load cell with the analog indicating system. This feature permits the selection of a wide number of full scale ranges not available from the internal force measuring system.

\section{CONTROL CONSOLE}

The majority of the machine operations are controlled and monitored from the control console which is located on the floor adjacent to the testing machine (fig. 2). Auxiliary controls are provided at convenient locations on both the movable work platform and the sensitive crosshead to facilitate their operation.

The hydraulic and electric controls for the loading and unloading operations for both the main and auxiliary pumps are manipulated from the console. Two sets of valves are provided to permit the machine operator to use coarse or fine control of the flow of hydraulic fluid to and from the main cylinder. This, in effect, lets the operator select a range of combinations from needle valve control of the low flow auxiliary pump to coarse valve control of the flow from the main pump. The fine control is useful in calibration set ups, which may require maximum crosshead motions in the order of 0.035 inch to apply the full calibration force. Coarse controls are generally used for testing less rigid structures where applications of the desired test loads may require crosshead motions up to the full 5 foot power stroke of the machine. 
As mentioned previously the force measuring system is monitored from the console on analog and/or digital indicating systems. These systems are conveniently located in front of the operator to aid in the manual control of the loading and unloading operation.

Other operations which can be controlled from the console are raising and lowering the movable work platform, locking and unlocking the backlash elimination system, and positioning both the tension and sensitive crossheads prior to testing.

\section{ACCESSORIES}

The machine is equipped with basic accessories such as compression and tension test fixtures, specimen restraining structures, a movable work platform, and load-handling equipment to facilitate the installation of test specimens in the machine.

A compression leveling plate assembly is mounted on the underside of the sensitive crosshead to accommodate nonparallel ends of compression specimens. This assembly, which can bear the full 12,000,000 lbf compression capacity of the testing machine, can be tilted as much as 0.5 inch, in a 60 inch diameter, toward any point of the compass.

To apply the full 6,000,000 1bf tension capacity to specimens, the machine is supplied with assemblies consisting of wedge blocks, nuts, spherical washers, tension rods, and either threaded couplings or clevis fixtures. One of each of these fixtures is shown in figure 5. Threaded couplings are available with 11-3ACME-2G and 15-3ACME-2G general purpose threads. Each pair of couplings is equipped with right and left hand threads to facilitate assembly. The clevis fixtures have 16 inch diameter pins, a 25 inch throat, and 12 inches clear between lugs to accommodate the tab ends of test specimens. In addition the machine is presently equipped with both flat and V-type wedge grips (fig. 5) which are capable of transmitting 3,000,000 lbf in tension to flat and round specimens, respectively. The flat grips can accommodate plate specimens up to 24 inches wide by 4 inches thick. The V-type grips can accommodate round specimens from 2.75 to 8 inches in diameter.

In the testing of large structural components, there is the ever present danger that the sudden release of energy due to abrupt specimen failure could cause considerable damage by expelling part or all of the specimen from the machine. In order to lessen this danger the machine is equipped with basic restraining structures, recoil assemblies, and other retaining devices which can be assembled into the machine as required.

Other accessories for the machine, which are independent of the testing equipment, are a movable work platform and load-handling equipment. These accessories are shown in figure 2. The movable work platform operates vertically along the four guide columns and is raised or lowered by electric motors which can be controlled from either the platform or from the testing machine control console. A ladder on one of the guide 
columns, which extends to the full height of the machine, provides convenient access to the platform at all positions above floor level. In order to facilitate the placement of test specimens in the machine, both the tension and the sensitive crossheads are equipped with loadhandling equipment. This equipment consists of pairs of monorails and hoists which are mounted on the underside of each crosshead as shown in figure 2. Each hoist on the tension crosshead can handle loads up to eight tons while each of those on the sensitive crosshead has a twelve ton capacity. Test specimens are raised from the floor or are transferred from a thirty-ton capacity overhead crane to these monorail hoists, and are then transported into the machine along the monorails.

\section{RESEARCH AND FORCE CALIBRATION}

For the first time it is possible to load large column sections up to $12,000,000 \mathrm{lbf}$. The heavy stub column shown in position between the bedplate and the sensitive crosshead of the machine in figure 6 has an estimated yield load of 7,200,000 1bf. The test of this $23 \mathrm{H} 681$ stub and its 36-foot long companion column have awaited the completion of this machine as no other existing machine offered the necessary size and load capacity

Other tests of fabricated columns, large eye bars, large diameter drill rod for undersea drilling operations, heavy specimens of wire rope, and structural configurations of column and beam connections are planned as future work for this unique testing machine.

This machine is also capable of applying forces for the calibration of force measuring devices having capacities up to $12,000,000$ 1bf. Calibrations of large elastic force measuring devices are made in this machine using a configuration similar to that shown in figure 7 . Here a large capacity load cell is compared with a group of smaller cells, each of which was calibrated previously against known force standards such as the NBS deadweight machines.

\section{SUMMARY}

Recognizing needs for a new large testing facility for large force calibrations and for full scale tests of large structural components, NBS has planned, developed, and placed in service a unique 12,000,000 lbf capacity universal testing machine which is believed to be the largest in the world. To extend the versatility of this machine the reinforced concrete foundation incorporates a floor tie-down system which will accommodate flexural test specimens up to 90 feet in length.

The use of this machine makes it possible to obtain information on the strength and behavior of structural components which because of their size and load capacity could not be tested previously. Plans discussed in the preceding section for force calibration and for tests of large structural components show the impact that the machine has on NBS programs. 
1. Mosley, T. J. and Griffith, J. H., What Our Large Testing Machines Have Accomplished, Engineering News-Record, 78, 4, April 26, 1917.

2. Griffith, J. H., and Bragg, J. G., Tests of Large Bridge Columns, Bureau of Standards Tech Paper No. 101, June 27, 1918. 


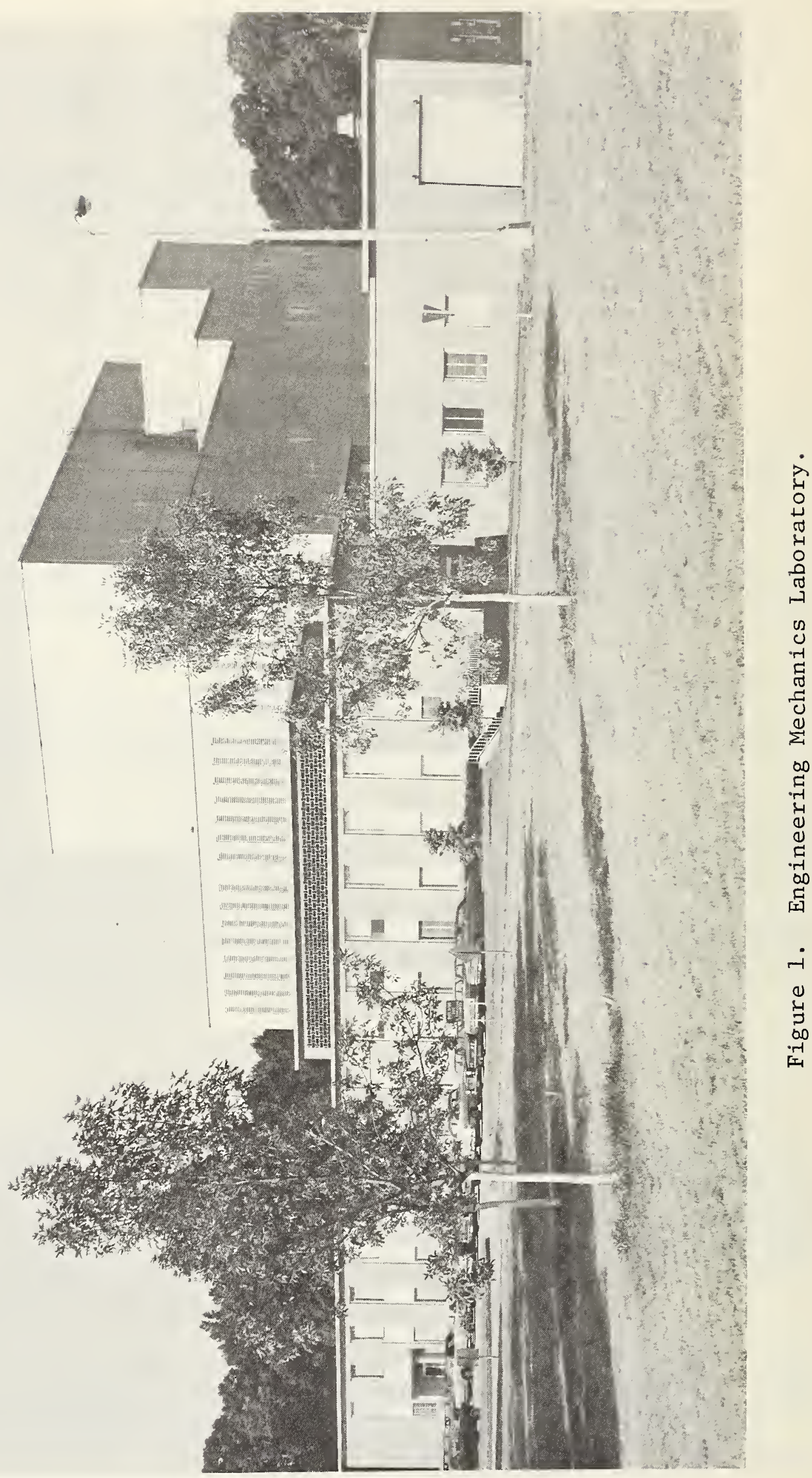




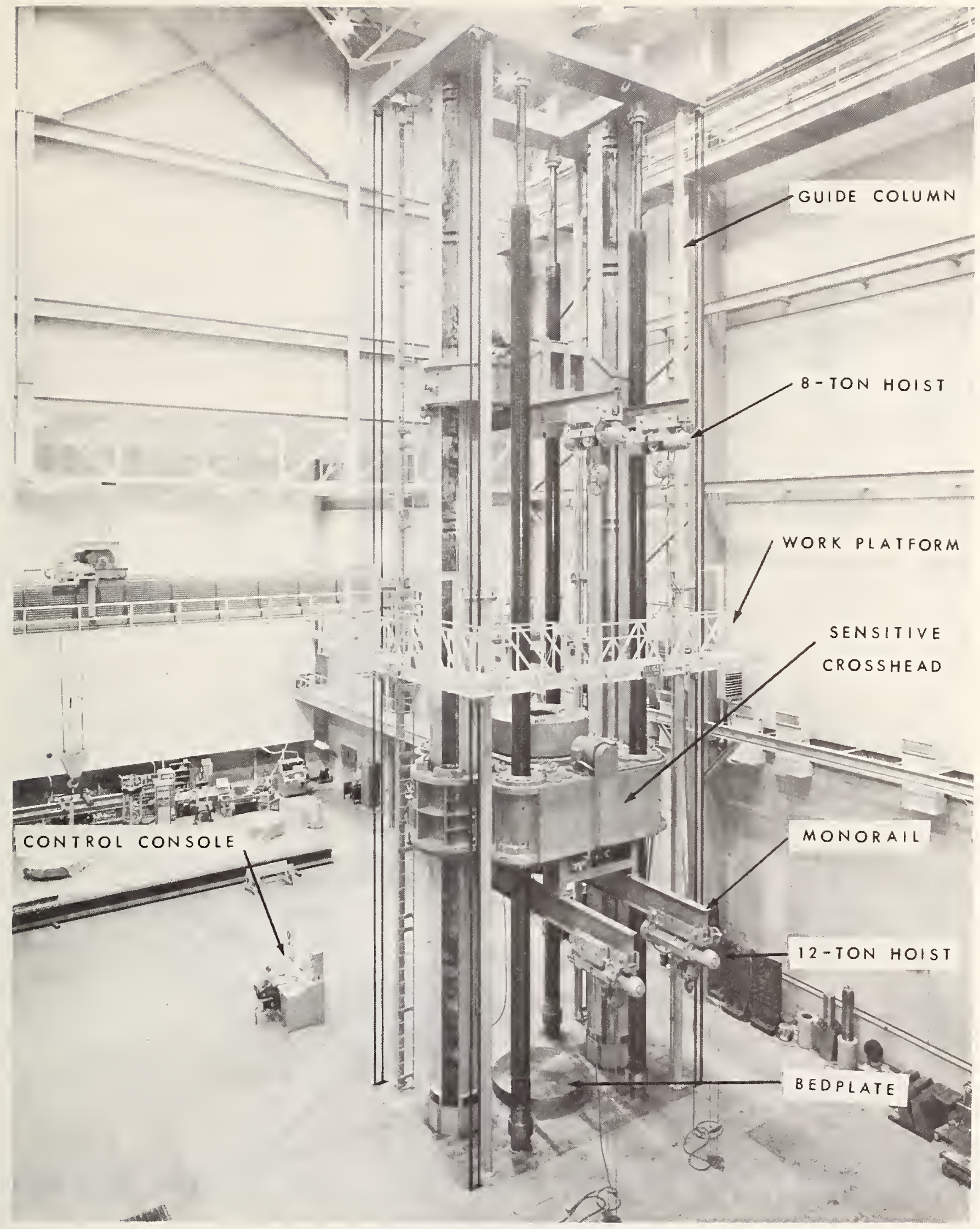

Figure 2. Universal testing machine of $12,000,000$ lbf capacity. 


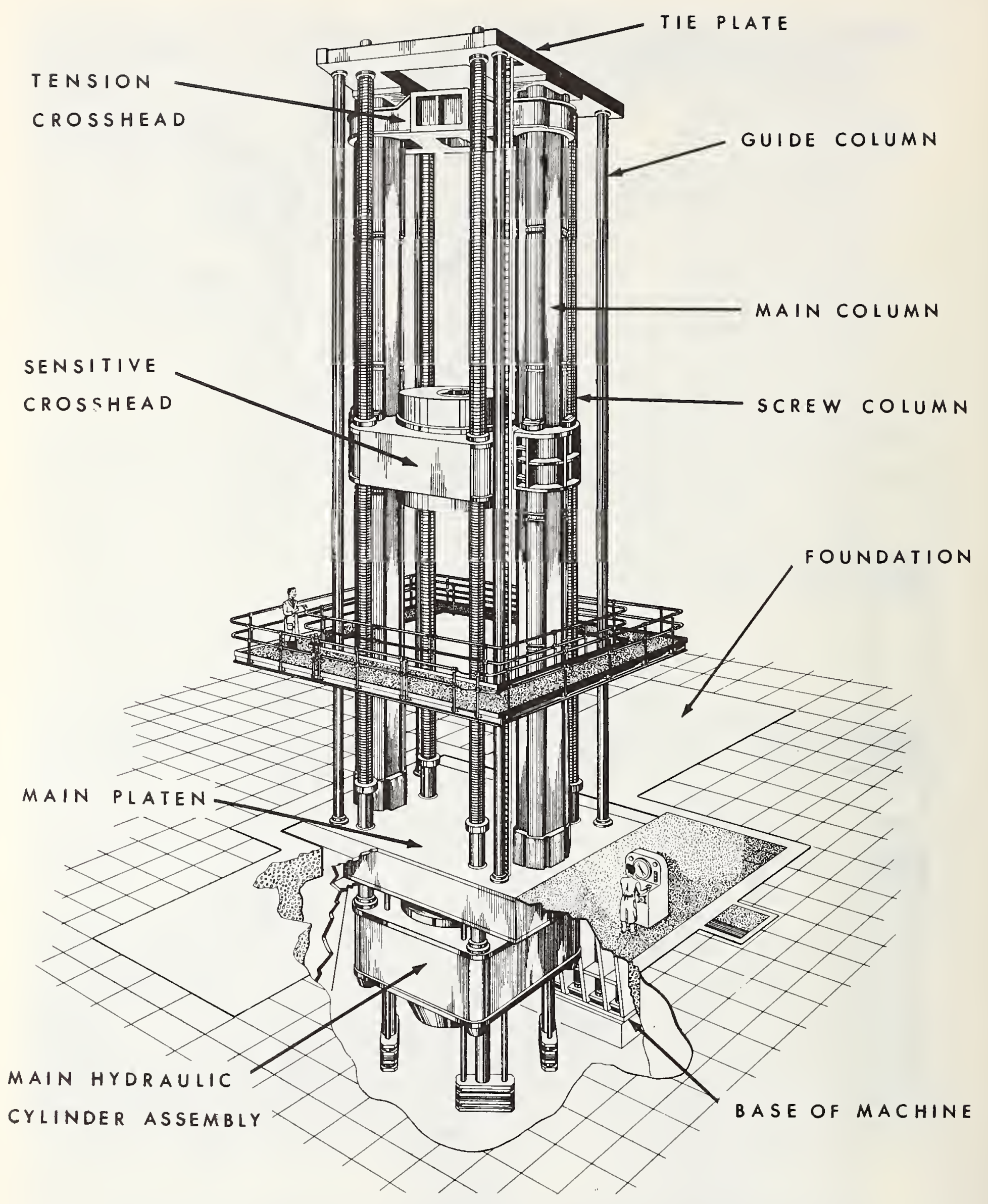

Figure 3. Drawing of the 12,000,000 Ibf capacity universal testing machine. 


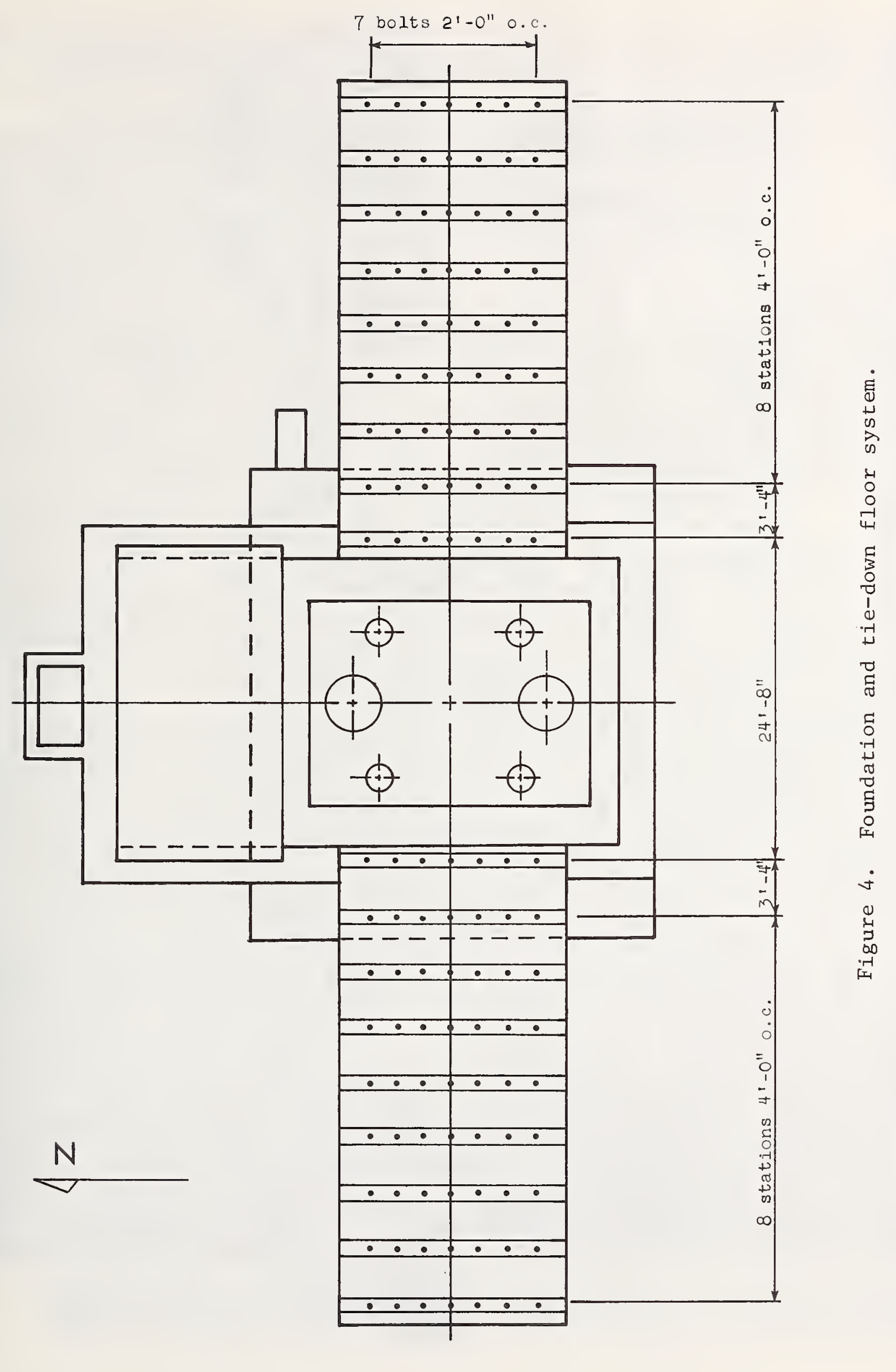




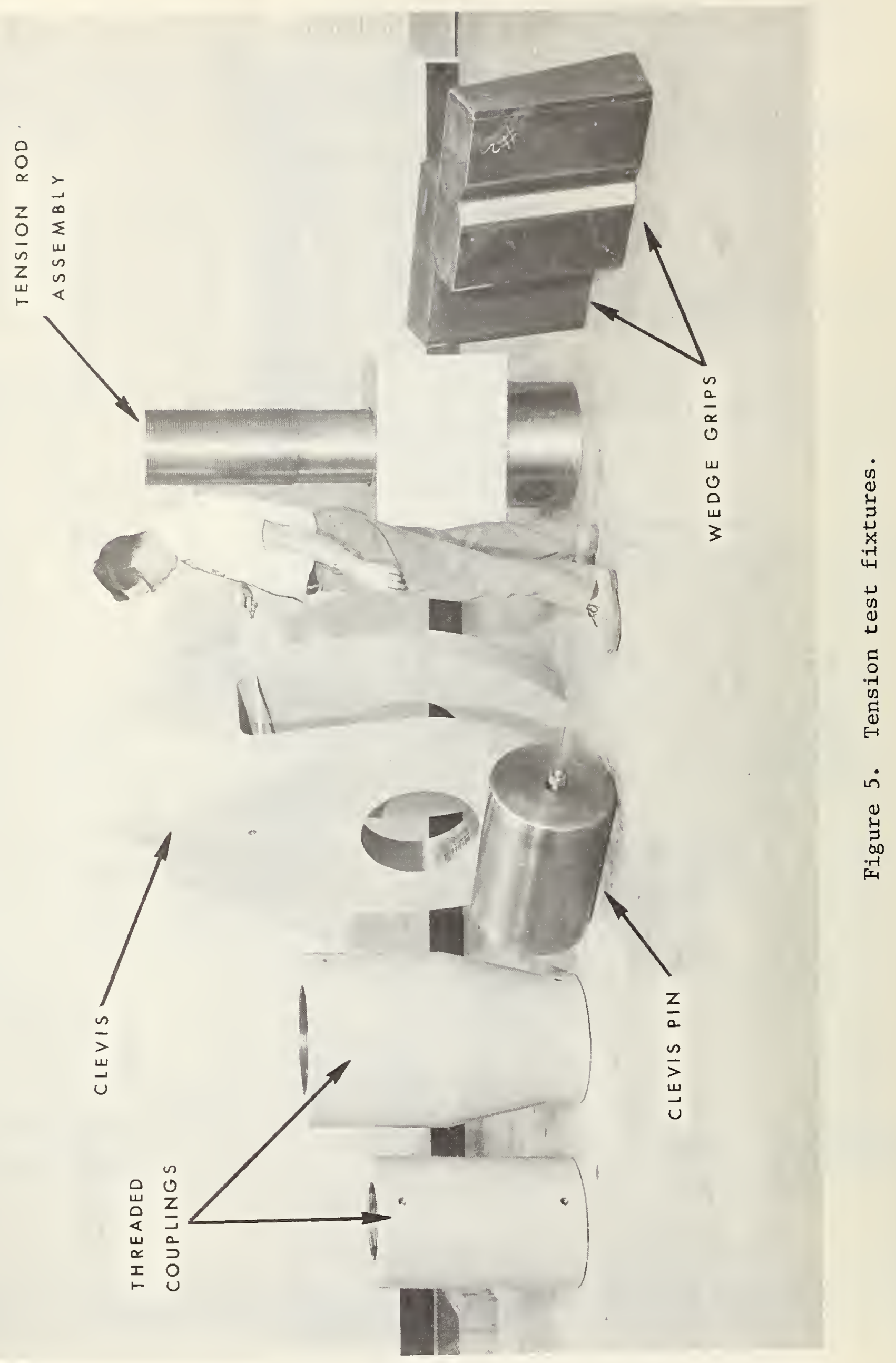




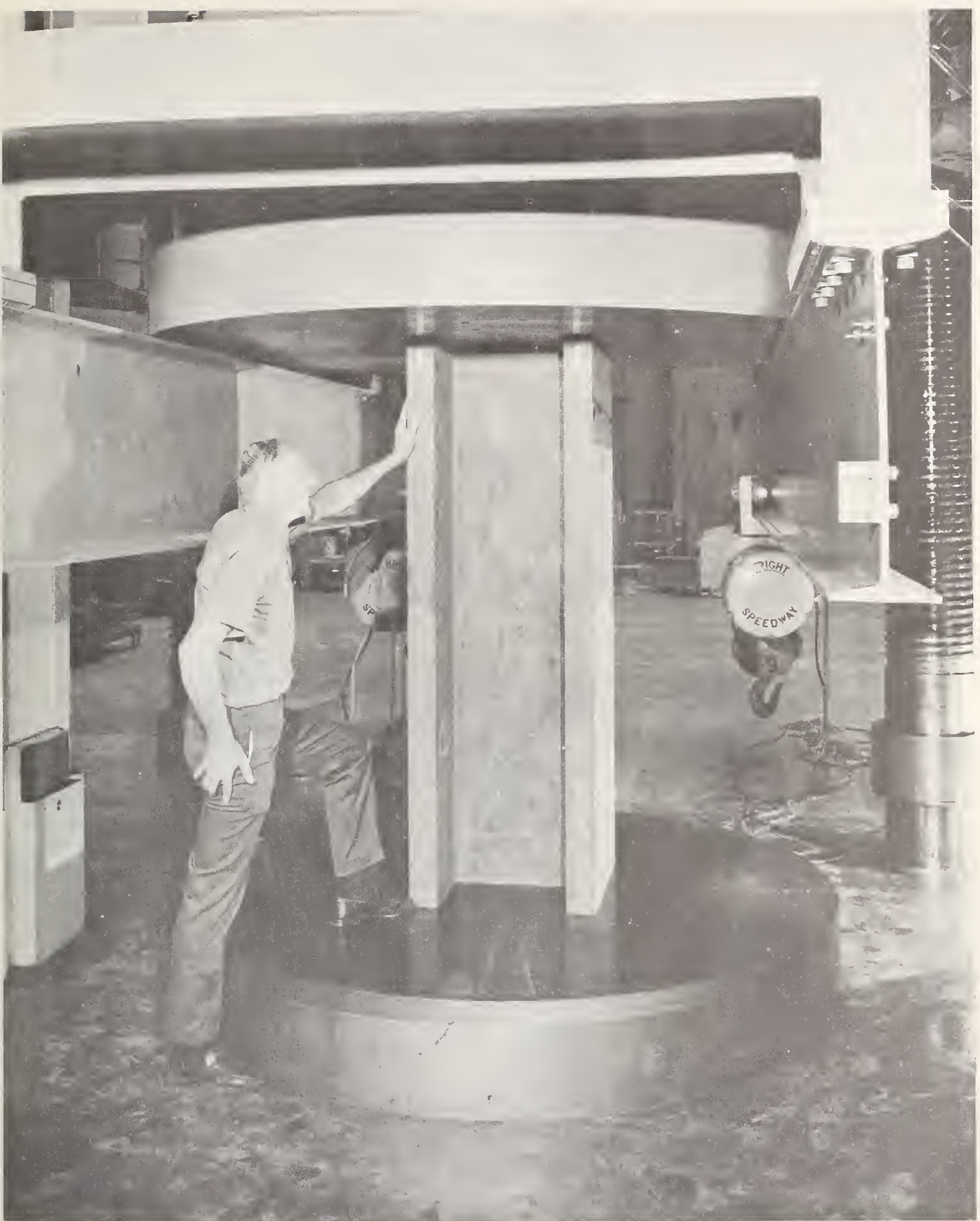

Figure 6. Heavy stub column in the $12,000,000$ lbf capacity universal testing machine. 


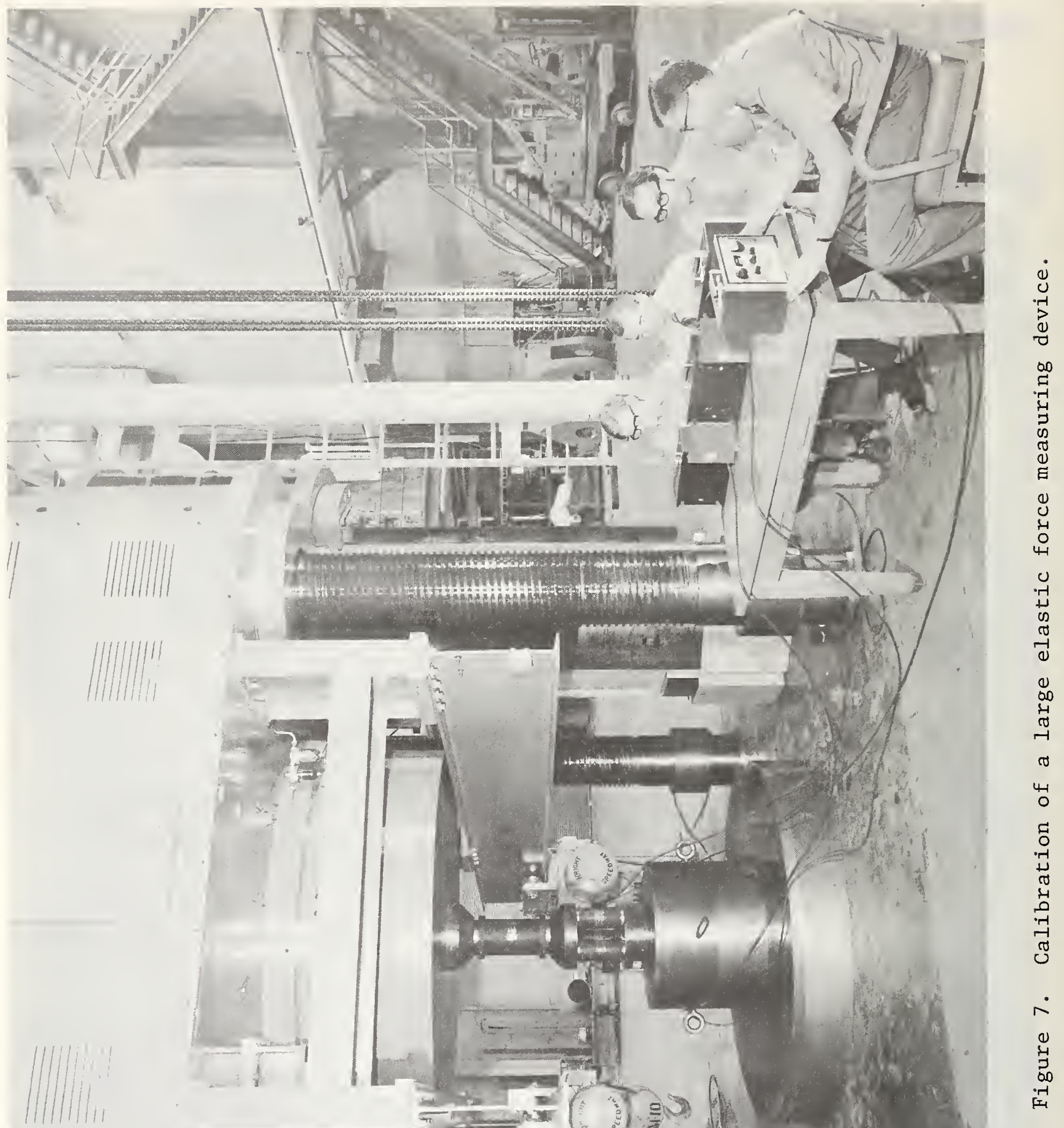

Winn *

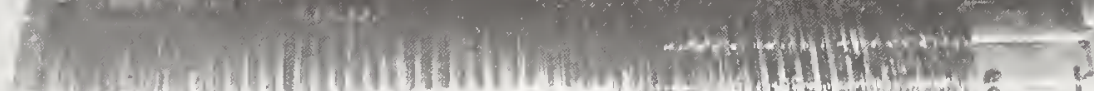
19.17. M) 
FORM NBS-114A (1.71)

\begin{tabular}{|c|c|c|}
\hline \begin{tabular}{c|c} 
U.S. DEPT. OF COMM. & 1. PUBLICATION OR REPORT NO. \\
BIBLIOGRAPHIC DATA & NBS-SP-355 \\
SHEET
\end{tabular} & $\begin{array}{l}\text { 2. Gov't Accession } \\
\text { No. }\end{array}$ & 3. Recipient's Accession No. \\
\hline 4. TITLE AND SUBTITLE & & $\begin{array}{l}\text { 5. Publication Date } \\
\text { September } 1971\end{array}$ \\
\hline $\begin{array}{l}\text { Universal Testing Machine of 12-Million-1bf } \\
\text { Capacity at the National Bureau of Standards }\end{array}$ & & 6. Performing Organization Code \\
\hline $\begin{array}{l}\text { 7. AUTHOR(S) } \\
\text { Arthur F. Kirstein }\end{array}$ & & 8. Performing Organization \\
\hline 9. PERFORMING ORGANIZATION NAME AND ADDRESS & & $\begin{array}{l}\text { 10. Project/Task/Work Unit No. } \\
2130141\end{array}$ \\
\hline $\begin{array}{l}\text { DEPARTMENT OF COMMERCE } \\
\text { WASHINGTON, D.C. } 20234\end{array}$ & & 11. Contract/Grant No. \\
\hline 12. Sponsoring Organization Name and Address & & $\begin{array}{l}\text { 13. Type of Report \& Period } \\
\text { Covered } \\
\text { Final }\end{array}$ \\
\hline Same as No. 9. & & 14. Sponsoring Agency Code \\
\hline
\end{tabular}

15. SUPPLEMENTARY NOTES

16. ABSTRACT (A 200-word or less factual summary of most significant information. If document includes a significant bibliography or literature survey, mention it here.)

A 12-million pounds-force capacity universal testing machine, which is believed to be the largest of its kind in the world, has been put into operation in the Engineering Mechanics Laboratory of the National Bureau of Standards in Gaithersburg, Maryland. This hydraulically operated machine, which has an overall height of over $100 \mathrm{feet}$, was designed to test full scale structural components and to apply the forces needed to calibrate large capacity force measuring devices. The testing machine is capable of applying axial forces of 12,000,000 $1 \mathrm{bf}$ in compression, $6,000,000 \mathrm{lbf}$ in tension, and a transverse force of 4,000,000 lbf to a flexural specimen.

17. KEY WORDS (Alphabetical order, separated by semicolons)

Force calibration; large test facilities; structural testing; universal testing machine.

18. AVAILABILITY STATEMENT

X] UNLIMITED

FOR OFFICIAL DISTRIBUTION. DO NOT RELEASE TO NTIS.

\begin{tabular}{|l|c|}
$\begin{array}{l}\text { 19. SECURITY CLASS } \\
\text { (THIS REPORT) } \\
\text { UNCL ASSIF IED }\end{array}$ & $\begin{array}{c}\text { 21. NO. OF PAGES } \\
18\end{array}$ \\
\hline $\begin{array}{l}\text { 20. SECUR ITY CLASS } \\
\text { (THIS PAGE) } \\
\text { UNCL ASSIFIED }\end{array}$ & $\begin{array}{c}\text { 22. Price } \\
30 \text { cents }\end{array}$ \\
\hline
\end{tabular}



JOURNAL OF RESEARCH reports National Bureau of Standards research and development in physics, mathematics, chemistry, and engineering. Comprehensive scientific papers give complete details of the work, including laboratory data, experimental procedures, and theoretical and mathematical analyses. Illustrated with photographs, drawings, and charts.

Published in three sections, available separately:

\section{- Physics and Chemistry}

Papers of interest primarily to scientists working in these fields. This section covers a broad range of physical and chemical research, with major emphasis on standards of physical measurement, fundamental constants, and properties of matter. Issued six times a year. Annual subscription: Domestic, $\$ 9.50 ; \$ 2.25$ additional for foreign mailing.

\section{- Mathematical Sciences}

Studies and compilations designed mainly for the mathematician and theoretical physicist. Topics in mathematical statistics, theory of experiment design, numerical analysis, theoretical physics and chemisty, logical design and programming of computers and computer systems. Short numerical tables. Issued quarterly. Annual subscription: Domestic, \$5.00; $\$ 1.25$ additional for foreign mailing.

\section{- Engineering and Instrumentation}

Reporting results of interest chiefly to the engineer and the applied scientist. This section includes many of the new developments in instrumentation resulting from the Bureau's work in physical measurement, data processing, and development of test methods. It will also cover some of the work in acoustics, applied mechanics, building research, and cryogenic engineering. Issued quarterly. Annual subscription: Domestic, $\$ 5.00$ : $\$ 1.25$ additional for foreign mailing.

\section{TECHNICAL NEWS BULLETIN}

The best single source of information concerning the Bureau's research, developmental, cooperative, and publication activities, this monthly publication is designed for the industry-oriented individual whose daily work involves intimate contact with science and technology-for engineers, chernists, physicists, research managers, product-development managers, and company executives. Annual subscription: Domestic, $\$ 3.00 ; \$ 1.00$ additional for foreign mailing.
Applied Mathematics Series. Mathematical tables, manuals, and studies.

Building Science Series. Research results, test methods, and performance criteria of building materials, components, systems, and structures.

Handbooks. Recommended codes of engineering and industrial practice (including safety codes) developed in cooperation with interested industries, professional organizations, and regulatory bodies.

Special Publications. Proceedings of NBS conferences, bibliographies, annual reports, wall charts, pamphlets, etc.

Monographs. Major contributions to the technical literature on various subjects related to the Bureau's scientific and technical activities.

\section{National Standard Reference Data Series.}

NSRDS provides quantitative data on the physical and chemical properties of materials, compiled from the world's literature and critically evaluated.

Product Standards. Provide requirements for sizes, types, quality, and methods for testing various industrial products. These standards are developed cooperatively with interested Government and industry groups and provide the basis for common understanding of product characteristics for both buyers and sellers. Their use is voluntary.

Technical Notes. This series consists of communications and reports (covering both other agency and NBS-sponsored work) of limited or transitory interest.

Federal Information Processing Standards Publications. This series is the official publication within the Federal Government for information on standards adopted and promulgated under the Public Law 89-306, and Bureau of the Budget Circular A-86 entitled, Standardization of Data Elements and Codes in Data Systems.

Consumer Information Series. Practical information, based on NBS research and experience, covering areas of interest to the consumer. Easily understandable language and illustrations provide useful background knowledge for shopping in today's technological marketplace.

NBS Special Publication 305, Supplement 1, Publications of the NBS, 1968-1969. When ordering, include Catalog No. C13.10:305. Price $\$ 4.50$; $\$ 1.25$ additional for foreign mailing. 


\section{U.S. DEPARTMENT OF COMMERCE}

National Bureau of Standards Washington, D.C. 20234

OFFICIAL BUSINESS

Penalty for Private Use, $\$ 300$
POSTAGE AND FEES PAID U.S. DEPARTMENT DF COMMERCE

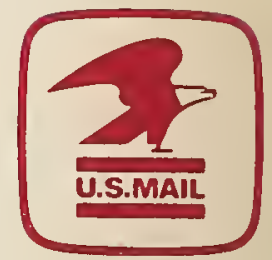

